\title{
Innovation and Development through Local Creative Industries: The Goldsmith Center in Caserta - Tarì
}

\author{
Mario Mustilli ${ }^{1}$, Filomena Izzo ${ }^{1,2}$, Domenico Graziano ${ }^{1,3}$ \\ ${ }^{1}$ Department of Economics, University of Campania 'Luigi Vanvitelli”, Capua (CE), Italy \\ Correspondence: Filomena Izzo, University of Campania 'Luigi Vanvitelli”, Capua (CE), Italy.
}

Received: August 7, 2017

doi:10.5539/ibr.v10n10p57
Accepted: September 5, $2017 \quad$ Online Published: September 7, 2017

URL: https://doi.org/10.5539/ibr.v10n10p57

\begin{abstract}
Creative industries are one of the main productive factors that fuel quality and competition; driving forces of the Italian economy. Creative industries are leading the economic growth all over the world through their techniques, among which are Co-creation and Design Thinking. New business models are being developed which are having positive effects on other business sectors and on the urban areas where they are located.

This research analyzes whether creative industries in the Goldsmith Center in Caserta (Tarì) are adopting the same innovative techniques (esp. Co-creation and Design Thinking) and if they are able to contribute to the territorial economic development.

Interviews were carried out to determine the awareness of the innovative techniques (Co-creation and Design Thinking) and their potential.

The results of the research indicate some confusion on the innovative techniques - Co-creation and Design Thinking - but there is a general consensus on the advantages, with positive effects on the local and/or regional business communities.

The results, in short, show that the craftsmanship of the goldsmiths in Caserta, or rather, the creative sector in question, can have some positive effects even on other business sectors in the province of Caserta and, therefore, on local development.
\end{abstract}

Keywords: creative industries, regional development, innovation capacity, co-creation, design thinking, Tarì

\section{Introduction}

The Cultural and Creative Productive System (cultural industries, creative industries, art history heritage, performing and visual arts, and creative-driven production) contributes to $6 \%$ of the wealth produced in Italy -89.9 billion Euros - 1.8\% growth compared to the previous year (Symbola, 2017). There is even more, considering that culture has a multiplying effect on the rest of the economy equal to $1.8 \%$. In other words, for every euro produced by culture, $1.8 \%$ is activated in other sectors. The 89.9 billion euros, therefore, "stimulate" another 160, reaching those 250 billion euros produced by the entire cultural chain $-16.7 \%$ of the national added value, with tourism benefiting the most from this growth booster. A confirmed growth booster for competition also because the geographic areas with higher revenues from culture are also those where manufacturing is strong. The Cultural and Creative Productive System (alone, without considering the other segments of the Italian economy) employs 1.5 million people $-6 \%$ of the total employed in Italy. This figure is also growing: $+1.5 \%$.

Looking at the dynamics of the sector, the impressive data is that, unlike the previous five-year period, all sectors record positive balance sheets, both in terms of added value as in employment. The most significant performances remain linked to the segments that had already shown positive signs in the past 5 years, such as design ( $+2.5 \%$ added value and $+1.9 \%$ employment), videogames $(+2.5 \%$ added value and $+1.7 \%$ employment), and creative driven production $(+1.7 \%$ added value and $+1.5 \%$ employment). Followed by, in particular, activities linked to the audiovisual sector $(+2.2 \%$ added value and $+1.4 \%$ employment), performing arts $(+2 \%$ added value and $2.2 \%$ employment $)$, and heritage $(+2.1 \%$ added value and employment).

Although talent remains at the heart of all these sectors, adding to the powerful dynamics is also the significant increase in the level of education required in the cultural and creative professions. Between 2011 and 2016, those who worked in the he Cultural and Creative Productive System and had a degree increased from $33 \%$ to $41 \%$ - 
noticeably higher than the rest of the economy - where there was an increase of less than 3 percentage points (from $17 \%$ to $20 \%$ ). Indicating that the sector has also identified increased competence as one of the answers to the crisis that has hit all sectors horizontally, especially those linked to the cultural core.

If we look beyond the perimeter of cultural and creative business, noticeably gaining the biggest advantage from the cultural boost is, in particular, as is expected, tourism - over one-third (37.9\%) of the national tourism expenditure is, in fact, activated by culture.

In the illustrated economic performances, signs of a widespread cultural unrest can be perceived, hitting all of society and, by osmosis, the economy. This confirms growth in traditional segments, joining culture and production, among which is artistic craftsmanship.

As Florida (2015) points out, the global creative economy is big business. The creative and cultural industries worldwide generated revenues of US $\$ 2,250$ billion (EY, 2015). According to the United Nations (UNCTAD, 2008), the creative industries are among the most dynamic sectors in world trade; in some developed and developing countries, the growth rate of creative industries exceeds the average growth rate of the whole economy (UNCTAD, 2008; Yu et al., 2014).

Researchers and policy-makers worldwide are now focusing on the creative industries' innovative processes and ideas across a wide variety of industries, largely due to the sector's economic growth (UNESCO, 2013; CIIC, 2013; Flew, 2014; EY, 2015; Izzo, 2017a,b). Creativity and innovation-which form the cornerstones of creative industries-are also being recognised as key drivers of productivity and living standards (EY, 2015; UNCTAD, 2008).

More studies have focused mainly on metropolitan areas rather than regions to measure the economic impact of the creative industries (Mahroum et al. 2007; Daniel, 2013; Daniel, Fleischmann \& Welters, 2016). On the other hand, Marrocu and Paci $(2012,355)$ show that 'It is now rare to see a metropolitan or a regional development plan which does not include among its strategic goals the attraction of creative individuals as the key determinant of local growth', hence identifying the importance of the regions.

Creative industries research and policy attention has without doubt increased over recent years; however, the role of creative industries as the vehicle for innovation, particularly in regional economies, is still an under-researched area.

Based on previous consideration, this paper will present current thinking on creative industries innovation in the context of economic development, how they innovate, and where Co-creation and Design Thinking fit into the global creative industries landscape.

Then, this paper explores the potential of economic development in a regional Italian city by the application of creative industries. This case study focuses on the province of Caserta (southern Italy).

The research explores the current role of the creative industries in Caserta as an enabler of innovation and hence the potential to drive economic development in the region. This study is one of the few to consider the creative industries in an innovation context of supply for creative services in other business sectors of the wider regional Caserta economy. As such, this study has wide-reaching implications for regional economies in not only Italia but also in other countries.

\subsection{What Are Creative Industries?}

In research and policy-making, there is no hard definition of creative industries. Currently, various classification systems for defining the cultural and creative industries exist (see UNCTAD, 2008; UNESCO, 2013; and also Florida, 2002 about creative class concept).

The definition most widely used so far in creative industries research was introduced and published by the United Kingdom (UK) Department of Culture Media and Sport (DCMS). It defines the creative industries as 'those industries which have their origin in individual creativity, skill and talent and which have a potential for wealth and job creation through the generation and exploitation of intellectual property' (DCMS 2001,5).The DCMS (1998) defined 13 creative industries sectors in 1998: Advertising; Architecture; Arts and Antiques Market; Crafts; Design; Designer Fashion; Film; Music; Performing Arts; Publishing; Software and computer services; Computer Games (Interactive Leisure Software); and Radio \& TV.

These sectors were updated in 2015 and were reduced to a list of nine: Advertising and Marketing; Architecture; Crafts; Design: Product, Graphic and Fashion design; Film, TV, Video, Radio and Photography; IT, Software and Computer services; Publishing; Museums, Galleries and Libraries; Music, Performing and Visual arts (DCMS, 2015,32). 


\subsection{How Do You Measure Creative Industries'Performance?}

Measuring innovation in creative industries is just as problematic as defining what constitutes a creative industry. First, it is known that the creative industries consist of a variety of diverse sectors, such as Architecture, Film and Software and the innovation performance of these sectors differs greatly (Müller, Rammer \& Trüby, 2009; Chapain et al. 2010; CIIC, 2013; Lee and Rodríguez-Pose, 2014).

Also, some researchers argue innovation outputs from creative industries cannot be measured easily by traditional metrics such as Research and Development (R\&D) investments or patents (Chapain et al., 2010; Edwards, 2013). Miles and Green $(2008,6)$ refer to these uncounted innovation outputs as 'hidden inno vations'. Other researchers point to 'aesthetic', 'artistic' or 'stylistic' elements in the creative industries innovative processes which are difficult to measure (Stoneman, 2009; Chapain et al.2010). Stoneman (2009: 105) calls these innovations 'soft innovations', they encompass 'for example, new books or music or changes in product aesthetics (sight, touch, smell) [which] can be economically important'.

As researchers grapple with definitions and innovation metrics, there is general agreement that economic necessity has forced economies and industries to become more creative to grow in order to survive the vagaries of global competition.

\subsection{What are the Innovative Mechanisms that Allow Creative Industries to be a Driver in Economic Development? Co-creation and Design Thinking: The Mechanics of Innovation.}

The Global Financial Crisis required businesses to find new ways to innovate and creative industries have played a role in that innovation. The creative industries have been particularly successful in supporting innovation by 'exporting' creative methodologies into other industries. Brown (2008, 2009) and Martin (2009) identified Co-creation and Design Thinking as a methodology to facilitate competitive advantages in businesses that have to innovate.

Although the direct contribution of creative industries to economic development has been quantified on a global scale, a relatively new research approach is to analyse the creative industries' contribution to economic development from an innovation perspective (Bakhshi and McVitte 2009; Lee \& Rodriguez-Pose, 2014; Fleischmann, Daniel \& Welters, 2017).

In general, creative industries are seen as having three roles in contributing to the innovation potential of an economy (Müller, Rammer \& Trüby, 2009; Reid, Albert \& Hopkins, 2010; UNCTAD, 2008; Bakhshi, McVittie \& Simmie, 2008; Chapain et al. 2010; Bakhshi, McVittie \& Simmie, 2008; Fleischmann, Daniel \& Welters, 2017: 123):

1. producing ideas and the commercialisation of these ideas which contribute (directly or indirectly) to the generation of new services and products;

2. providing innovation impulses to technology producers because creative industries are intensive users of technology and often demand adaptations and new developments of technology;

3. offering creative services which can input to innovative activities of businesses and organisations within and outside the creative industries.

Another form of knowledge transfer from the creative industries to another business sector is defined by Lee and Rodriguez-Pose $(2014,1140)$ as 'learnt innovation'. This happens when embedded creatives-who are being employed in other industry sectors-contribute to innovation activities in these sectors. The important role of these embedded creatives has attracted research attention in recent years (e.g. Higgs et al. 2010; Hearn and Bridgstock, 2014; Rodgers 2015; Fleischmann and Daniel 2015) with Lee and Rodriguez-Pose (2014) demonstrating that embedded creatives are likely to drive process innovations by their propensity to move fluidly between work roles and bring with them advanced knowledge of new techniques and processes.

Companies have begun shifting away from product-centric thinking and have begun focusing on a collaborative approach to innovation and design (Prahalad and Ramaswamy, 2004; Tanev, Knudsen, and Gerstlberger, 2009). Searching for breakthrough ideas to stay competitive in the global marketplace has prompted companies to employ strategies and practices of value creation which focus on customer involvement in product, process and service innovation (Burdon, Mooney, and Al-Kilidar, 2015; Romero and Molina 2011; Bason, 2010; Rovnan, 2014; Bason, 2010). Such new practices include Co-creation which takes a human-centred approach to innovation.

Starbucks and DHL are only two examples for this new form of open innovation engagement which invites the ideas from the public (Duffy and Partners, 2008; Thierer, 2010). Ultimately, the 'collective design' (Maher, 
Paulini, and Murty 2010) creates what people really want and need. Ramas wamy (2010) argues persuasively that managers and business leaders need to recognise and embrace the Co-creation shift to remain on the forefront of value creation. Studies support Ramaswany's conclusions by showing that businesses or organisations that engage in the Co-creation processes perform better and have products that are more profitable than those resulting from traditional market research techniques (Gustafsson, Kristensson and Witell, 2012).

While Co-creation supports innovation processes in businesses and organisations, some researchers suggest that Co-creation facilitates incremental innovation only. Gustafsson, Kristensson and Witell $(2012,322)$ argue that the creation of radical solutions are 'unthinkable' for end users involved in the Co-creation process because they base their thinking and contributions on previous experiences.

Solutions that are 'truly radical' are, therefore, difficult to achieve in the Co-creation process (Gustafsson, Kristensson and Witell $(2012,321)$. Leavy $(2012,27)$ suggests that while businesses must 'empower the user as active collaborator' and hence should engage in Co-creation practices, they also need to make a transition to Design Thinking which supports the creation of radical ideas. These ideas are ultimately needed for radical innovation, which Leifer et al. (2001 in Berg et al., 2016, 43) sees as a 'product, process or service, with either exceptional performance features or familiar features offering significant improvements in performance, or costs that transform existing markets or create new ones'.

What makes Design Thinking successful in developing breakthrough ideas is that the Design Thinking process focuses on building empathy, fast learning, bringing more than one idea forward, rapid prototyping and iteration of solutions through user feedback. It is a quick process and requires keeping an open mind towards various solutions. Therefore, Design Thinking differs from traditional approaches of re-design where the search for the single right answer or solutions can kill creativity and innovation (Liedtke and Ogilvie, 2011).

Similar to Co-creation, Design Thinking requires a close relationship with customers or end-users who provide new perspectives from unique viewpoints (Simons, Gupta, and Buchanan, 2011). Teamwork and input from multiple disciplines are necessary to succeed when applying the Design Thinking process.

Many businesses have successfully employed the Design Thinking methodology and have started to create a design-led culture in daily operations. A well-known example are Airbnb (First Round Review, 2015; Winkler, 2015), Uber (Prasad, 2014; Clayton, Raynor, and McDonald, 2015; Horn, 2016), and SAP (Rao, 2015; SAP, 2016). Success stories of larger cooperation such as Airbnb, Uber and SAP are well known but Ward, Runcie and Morris (2009) argue that Design Thinking and design-led innovation can also propel innovation in small and medium sized businesses.

\section{Method}

The study explores the innovation capacity of the creative industries in Goldsmith Center in Caserta (Tarì) and hence identify the role the sector can play to progress the local economy. In order to identify future areas for investing in the sustainable development of creative industries and possible current gaps, the following research question is investigated: are the creative industries facilitating innovation in other sectors of the local/regional economy through their services?

To answer this question, data from Tarì's creative industries businesses (supply side) was collected.

Interview questions (during 2017) for supply of human-centred innovation methodologies (Co-creation and Design Thinking) were used as indicators to explore the innovation capacity of the creative industries in Goldsmith Center in Caserta. In order to this, Dr Floriana Marino (Marketing Director of the Tarì) and Vincenzo Giannotti (President of the Tarì) were interviewed.

Respondents were asked to report on following topics (Fleishmann, Daniel and Welters, 2017):

1. Character of the creative service provided to clients

a. Improved current needs of end users

b. Satisfied unmet needs of end user

c. New to client's business

d. Had potential for significant innovation

e. Produced novel insights

f. New to the market

g. Novel 

h. New to the world
i. New to the industry

2. Which of the following do you offer or actively promote as part of your service package to your clients?
a. Design Thinking
b. Brainstorming
c. Co-creation
d. Other

3. Level of use of Co-creation and Design Thinking when working on projects for clients
a. Always
b. Often
c. Rarely
d. I have heard of it but do not use it
e. I have not heard of it
f. I have heard of it but do not use it because it is not relevant for my business

4. Which approaches are used when working on a typical creative project?
a. Involve the client directly in the project development process
b. Collaborate with others outside your business
c. Work on the project alone
d. Work in a collaborative team within your business
e. Involve the end user of the service/product by including research about the end user
f. Involve the end user of the service/product directly in the project development process

\section{Results}

The Goldsmith Center - Tarì was established in 1996 from the intuition of a group of young Neapolitan entrepreneurs who choose to follow the concepts of sharing and centralization of the precious goldsmith culture and tradition. The name Tarì, the name of an ancient gold Arabian coin widely used in the Kingdom of Naples until the Aragonese era, is used as a symbol and witness to the historical authenticity.

The simplicity of the word, easily pronounced in all languages, its historic roots, the identifying with the precious product, make it the most suitable identification of a place where tradition and innovation are the two sides of the same coin.

Operational now for 20 years, the Tarì represents an undisputed point of reference for goldsmiths, so much so that it is recognized as "best practice" in the field, both at the national as the international levels. The common spaces, the squares, the pavilions, the businesses that are operational daily in the Center, contribute to making the Tarì an incomparable place where the organization's values of freedom of movement, enhancement of individual uniqueness, and focus on quality are given space and emphasis.

It is a symbol of entrepreneurial challenge, of organizational ability, of the sharing of goals that still now, 20 years from its conception, is unparalleled in Italy, or on an international level. All of this, tied to a realm that expresses, in turn, the best of the Italian creativity - the Jewel.

Since 1996, the Tarì has been the new way of doing business. A concept of co-working that focuses on individual personality. A project that is constantly evolving, dedicated to the jewel.

Tradition and creativity is the DNA of the Tarì. The daily comparison with the market inspires the evolution of associated businesses. A world of craftsmen and services that constantly supports the needs of goldsmiths. The Tarì believes in the Difference - quality is measured through management.

The Tarì's areas and services are always open to new forms of expression and experimentation. "We organize successful fairs and events because we believe in the power of ideas".

The Tarì is a heritage esteemed worldwide: 400 enduring entrepreneurs see to it that the Tarì is the point of reference in production and distribution of valuables. 
It covers about 135,000 sq.m. in total - 40,000 of which are permanently dedicated to associate production and distribution, plus a 9,500 sq.m. exhibition area.

The turn-out rate is also indicative:

- Over 3,500 professionals are present at the Tarì every day

- Over 400,000 operators in the sector per year

- 500 permanent businesses (30\% production, $30 \%$ services, and $40 \%$ distribution)

- 2,500 agents

- Daily turn-out of 3,500 (7,000 during the fairs)

- 3 specialized exhibitions per year with a turn-out of over 25,000 per event, with the participation of the 400 internal businesses and 100 external ones

- 850 million euros in sales per year $-30 \%$ for export (mainly to European and Mediterranean countries, the United States, Russia and China)

Respondent was asked to report on the character of the creative service provided to clients (topic 1). Findings suggest creative industries service providers consider themselves a source of significant innovation potential. Typical criteria that can drive innovation have all received positive feedback. These criteria are outcomes that 'satisfy unmet needs of end user', had 'significant potential for innovation', were 'new to the market' and 'new to the world'.

Topic number 2 explores which creative methods that facilitate innovation activities are actively promoted by Tari's creative industries. The feedback shows that Tarì offer or actively promote innovation methodologies co-creation as part of their service package for clients.

The feedback on topic number 3 (on the level of familiarity and use of Co-creation and Design Thinking). Survey respondent reported 'often' apply Co-creation, rarely Design Thinking.

The feedback on topic number 4 (which approaches are used when working on a typical creative project) reveals positive aspects of how creative industries approach projects that could facilitate innovation. Tarì's creative industry businesses engage in collaborative team within own business.

\section{Discussion}

This study explored the current role of the Tari's creative industries as an enabler of innovation with the potential to drive economic development in Caserta (and regional) area .

This research provided valuable insights about the innovation potential of the regional creative industries sector in Caserta. Findings clarified the current supply for creative services in the local economy.

It is clear from the responses that there is an unexploited potential to grow the inno vation capacity in Caserta. The research has shown that Tari's creative industries reported that the work done for clients had potential for significant innovation and that their services had helped clients to enter new markets with their products and services.

The results of the research indicate some confusion on the innovative techniques - Co-creation and Design Thinking - but there is a general consensus on the advantages, with positive effects on the local and/or regional business communities.

The study points out that there is potential innovation capacity in Caserta (and regional) economy through the creative industries, but only if the Tari's creative industries 'open' themselves more to the business environment.

The main limitation is attributable to the fact that this research doesn't give information on demand side. That is, the demand for creativity and inno vation support in other business sectors of Caserta's business community. This interesting aspects to be explored in future research.

\section{Acknowledgments}

Many thanks to Dr. Floriana Marino and to the President of the Tarì, Vincenzo Giannotti, for their precious collaboration.

\section{References}

Bakhshi, H., \& Mc Vitte, E. (2009). Creative Supply-chain Linkages and Innovation: Do the Creative Industries Stimulate Business Innovation in the Wider Economy? Innovation: Management, Policy \& Practice, 11, 169-189. https://doi.org/10.5172/impp.11.2.169 
Bakhshi, H., McVittie, E., \& Simmie, J. (2008). Creating Innovation: Do the Creative Industries Support Innovation in the Wider Economy? London: NESTA.

Bason, C. (2010). Leading Public Sector Innovation: Co-Creating for a Better Society. Bristol: Policy Press.

Berg, P., Pihlajamaa, J., Hansen, P. K, \& Mabogunje, A. (2016). Measurement of Design Front End: Radical Inno vation Approach. In Design Thinking for Innovation: Research and Practice, edited by Walter Brenner and Falk Uebernickel, 41-56. Schwitzerland: Springer. https://doi.org/10.1007/978-3-319-26100-3_3

Brown, T. (2008). Design Thinking. Harvard Business Review, 86(6), 84.

Brown, T. (2009). Change by Design: How Design Thinking Transforms Organizations and Inspires Innovation. New York: HarperCollins.

Burdon, S., Mooney, G. R., \& Al-Kilidar, H. (2015). Navigating Service Sector Innovation Using Co-Creation Partnerships. Journal of Service Theory and Practice, 25(3), 285-303. https://doi.org/10.1108/JSTP-08-2013-0164

Chapain, C., Cooke, P., De Propris, L., MacNeill, S., \& Garcia, J. M. (2010). Creative Clusters and Innovation: Putting Creativity on the Map. London: NESTA.

CIIC (Creative Industries Innovation Centre). (2013). Valuing Australia's Creative Industries. Canberra: An Australian Government Initiative.

Clayton, M., Raynor, E., \& McDonald, R. (2015). What Is Disruptive Innovation? Harvard Business Review, Dec. Issue, 44-53.

Daniel, R. (2013). Regional creative industries in Australia: Exploring Towns ville as a case study. Creative Industries Journal, 6(2), 113-128. https://doi.org/10.1386/cij.6.2.113_1

Daniel, R., Fleischmann, K., \& Welters, R. (2016). Creativity in the 'Torrid' Zone: Policy, Creative Industries and the Vision for Northern Australia. International Journal of Cultural Policy. https://doi.org/10.1080/10286632.2016.1221949

DCMS. (1998). Creative Industries Mapping Document. London: Department of Culture, Media \& Sport.

DCMS. (2001). Creative Industries Mapping Document. London: Department of Culture, Media \& Sport.

DCMS. (2015). Creative Industries Mapping Document. London: Department of Culture, Media \& Sport.

Duffy \& Partners (2008). Why the Democratization of Design is a Good Thing - Really. AdWeek, June 20. http://www.duffypov.com/duffy-article/1505/why-the-democratization-of-design-is-agood-thing-really

Edwards, G. (2013). Regions and Innovation: A Reflection. In Regional Advantage and Innovation: Achieving Australia's National Outcomes, edited by Susan Kinnear, Kate Charters and Peter Vitartas, 151-168. Berlin Heidelberg: Springer-Verlag. https://doi.org/10.1007/978-3-7908-2799-6_7

EY. (2015). Cultural Times: The First Global Map of Cultural and Creative Industries. New York, NY: CIS AC The International Confederation of Societies of Authors and Composers.

First Round Review. (2015). How Design Thinking Transformed Airbnb from a Failing Startup to a Billion Dollar Business. First Round Review.

http://firstround.com/review/How-design-thinkingtransformed-Airbnb-from-failing-startup-to-billion-dollar -business/

Fleischmann, K., \& Daniel, R. (2015). The Rise of the Embedded Designer in the Creative Industries. Journal of Education and Work, 28(4), 422-442. https://doi.org/10.1080/13639080.2014.997687

Fleischmann, K., Daniel, R., \& Welters, R. (2017). Developing a regional economy through creative industries: innovation capacity in a regional Australian city. Creative Industries Journal, 10(2), 119-138. https://doi.org/10.1080/17510694.2017.1282305

Flew, T. (2014). Creative Industries - A New Pathway. InterMedia, 42(1), 11-13.

Florida, R. (2002). The Rise of the Creative Class. New York: Basic Books.

Florida, R. (2015). The Global Creative Economy Is Big Business. CityLab 2016. http://www.city lab.com/work/2015/12/the-global-creative-economy-is-big-business/422013/

Gustafsson, A., Kristensson, P., \& Witell, L. (2012). Customer Co-Creation in Service Innovation: A Matter of Communication? Journal of Service Management, 23(3), 311-327. https://doi.org/10.1108/09564231211248426 
Hearn, G., \& Bridgstock, R. (2014). The Curious Case of the Embedded Creative: Creative Cultural Occupations Outside the Creative Industries. In Handbook of Management and Creativity, edited by Chris Bilton and Stephen Cummings, 39-56. Cheltenham: Edward Elgar Publishing. https://doi.org/10.4337/9781781000977.00011

Higgs, P., Freebody, S., Anderson, P., \& Cunningham, S. (2010). What's your other Job? A Census Analysis of Arts Employment in Australia. Sydney: Australia Council for the Arts.

Horn, M. (2016). Uber, Disruptive Innovation And Regulated Markets. Forbes, June 20. http://www.forbes.com/sites/michaelhorn/2016/06/20/uber-disruptive-innovation-and-regulated-markets/\#7 $144585 \mathrm{a} 3359$

Izzo, F. (2017a). Musei e tecnologie: valorizzare il passato per costruire il futuro. Milano: Cedam,

Izzo, F. (2017b). Equity Crowdfunding for Cultural Startup: The Case of Italy. World Journal of Social Sciences, 7(1), 130-135.

Leavy, B. (2012). Collaborative Innovation as the new Imperative - Design Thinking, Value Co-Creation and the Power of "pull". Strategy \& Leadership, 40(2), 25-34. https://doi.org/10.1108/10878571211209323

Lee, N., \& Rodriguez-Pose, A. (2014). Creativity, Cities, and Innovation. Environment and Planning, A46, 1139-1159. https://doi.org/10.1068/a46202

Liedtke, J., \& Ogilvie, T. (2011). Designing for Growth: A Design Thinking Tool Kit for Managers. New York: Columbia University Press.

Maher, M. L., Paulini, M., \& Murty, P. (2010). Scaling up: From Indi vidual Design to Collaborative Design to Collective Design. Paper read at 4th International Conference on design Computing and Cognition (DCC), Stuttgart, July 12-14.

Mahroum, S., Atterton, J., Ward, N., Williams, A., Naylor, R., Hindle, R., \& Rowe, F. (2007). Rural Innovation. London: NESTA: National Endowment for Science, Technology and the Arts.

Marrocu, E., \& Paci, R. (2012). Regional Development and Creativity. International Regional Science Review, 36(3), 354-391. https://doi.org/10.1177/0160017612461915

Martin, R. (2009). The Design of Business: Why Design Thinking is the Next Competitive Advantage. 3rd ed. Massachusets, MA: Harvard Business Review Press.

Miles, I., \& Green, L. (2008). Hidden Innovation in the Creative Industries. London: NESTA.

Müller, K., Rammer, C., \& Trüby, J. (2009). The Role of Creative Industries in Industrial Innovation. Innovation: Management, Policy \& Practice, 11, 148-168. https://doi.org/10.5172/impp.11.2.148

Prahalad, C. K., \& Ramaswamy, V. (2004). Co-creation Experiences: The next Practice in Value Creation. Journal of Interactive Marketing, 18(3), 5-14. https://doi.org/10.1002/dir.20015

Prasad, A. (2014). Applying Design Thinking at the Organizational Level (Uber). Paper presented at the $U X$ Week Conference, San Francisco, USA, September 10-12.

Ramaswamy, V. (2010). Competing through Co-creation: Innovation at two Companies. Strategy \& Leadership, 38(2), 22-29. https://doi.org/10.1108/10878571011029028

Rao, M. (2015). Problem Solving with Design Thinking: 10 Stories, Tools and Tips. Your Story 2015. https://yourstory.com/2015/05/problem-solving-with-design-thinking/

Reid, B., Albert, A., \& Hopkins, L. (2010). A Creative Block? The Future of the UK Creative Industries. London: The Work Foundation.

Rodgers, J. (2015). Jobs for Creatives Outside the Creative Industries: A study of Creatives Working in the Australian Manufacturing Industry. Creative Industries Journal, 8(1), 3-23. https://doi.org/10.1080/17510694.2015.1034572

Romero, D., \& Molina, A. (2011). Collaborative Networked Organisations and Customer Communities: Value Co-Creation and Coinno vation in the Networking Era. Production Planning \& Control, 22(5-6), 447-472. https://doi.org/10.1080/09537287.2010.536619

Rovnan, J. (2014). Everyone' is Now a Designer? In Design Thinking, edited by Matt Lyons, Discussion Group: Design Thinking: LinkedIn

SAP. (2016). Design Thinking with SAP. https://designthinkingwithsap.com/ 
Simons, T., Gupta, A., \& Buchanan, M. (2011). Innovation in R\&D: Using Design Thinking to Develop new Models of Inventiveness, Productivity and Collaboration. Journal of Commercial Biotechnology, 17(4), 301-307. https://doi.org/10.1057/jcb.2011.25

Stoneman, P. (2009). Soft Innovation: Towards a More Complete Picture of Innovative Change. London: NESTA.

Symbola. (2017) Rapporto Io sono Cultura 2017 - L'Italia della qualità e della bellezza sfida la crisi http://www.symbola.net/html/article/iosonocultura17ricerca

Tanev, S., Knudsen, M., \& Gerstlberger, W. (2009). Value Co-creation as Part of an Integrative Vision of Innovation Management. Technology Innovation Management (TIM) Review. http://timreview.ca/article/309

Thierer, A. (2010). The Case for Internet Optimism, Part 1: Saving the Net from Its Detractors. In The Next Digital Decade: Essays On The Future Of The Internet, edited by Berin Szoka and Adam Marcus, 57-88. Washington, DC: TechFreedom.

UNCTAD. (2008). Creative Economy Report. New York: The United Nations Conference on Trade and Development.

UNESCO. (2013). Creative Economy Report, Special Edition, Widening Local Development Pathways. New York, NY: United Nations Educational, Scientific and Cultural Organization (UNESCO) and United Nations Development Programme (UNDP).

Ward, A., Runcie, E., \& Morris, L. (2009). Embedding Innovation: Design Thinking for Small Enterprises. Journal of Business Strategy, 30(2/3), 78-84. https://doi.org/10.1108/02756660910942490

Winkler, R. (2015). Airbnb Raises Over $\$ 100$ Million as It Touts Strong Growth. Wall Street Journal http://www.wsj.com/articles/airbnb-raises-over-100-million-as-it-touts-strong-growth-1448049815

Yu, W., Hong, J., Zhu, Y., Marinova, D., \& Guo, X. (2014). Creative Industry Clusters, Regional Inno vation and Economic Growth in China. Regional Science Policy \& Practice, 6(4), 329-348. https://doi.org/10.1111/rsp3.12051

\section{Copyrights}

Copyright for this article is retained by the author(s), with first publication rights granted to the journal.

This is an open-access article distributed under the terms and conditions of the Creative Commons Attribution license (http://creativecommons.org/licenses/by/4.0/). 